\title{
STUDIES ON THE IMMUNE RESPONSE OF THE RHEUMATIC SUB- JECT AND ITS RELATIONSHIP TO ACTIVITY OF THE RHEU- MATIC PROCESS. VI. THE SIGNIFICANCE OF THE RISE OF ANTISTREPTOLYSIN LEVEL IN THE DEVELOPMENT OF RHEUMATIC ACTIVITY ${ }^{1}$
}

\author{
By ALVIN F. COBURN AND RUTH H. PAULI \\ (From the Department of Medicine, College of Physicions and Surgeons, Columbia University, \\ and the Presbyterian Hospital, New York City)
}

(Received for publication June 3, 1935)

The authors have observed that respiratory infection with a strain of hemolytic streptococcus producing strong toxin is not invariably followed by rheumatic recrudescence ${ }^{2}$ in a susceptible subject. This observation has been made under several different circumstances. (a) Two rheumatic children escaped rheumatic activity in spite of infection with a strain of hemolytic streptococcus that produced severe recrudescences in fourteen others living in the same home (1). (b) Infections with a scarlatinal strain of hemolytic streptococcus, occurring simultaneously in two rheumatic siblings were followed by rheumatic attacks, one of which was severe and prolonged, the other extremely mild (2). (c) Scarlet fever in one rheumatic subject under close observation was followed by only mild carditis. (d) Several of the strains described in the fourth paper of this series (2) produced strong toxin and streptolysin but were not effective in initiating recrudescences. The one characteristic common to all of these individuals who escaped attacks was the failure to develop a significant rise in antistreptolysin titer. The present paper deals with the significance of changes in antistreptolysin level in the rheumatic subject.

\section{The natural antistreptolysin level and the average range in good health}

It has already been shown (3) that the natural antistreptolysin level in subjects who have been free of hemolytic streptococcus infection is ap-

1 The work reported in this communication was carried out under The W. K. Kellogg Foundation.

2 The term "recrudescence" is applied to the development of an acute attack in a known rheumatic subject, following a period of quiescence. It is not to be confused with an exacerbation of symptoms, such as may occur late in a polycyclic rheumatic attack. proximately 50 units. The range of titers to be expected in apparently healthy persons living in New York City was determined in a study of 146 individuals of various ages. They are reported in five groups as specified in Table I.

TABLE I

The frequency of high and low antistreptolysin titers among several groups of subjects living in New York City

\begin{tabular}{|c|c|c|c|}
\hline \multirow[b]{2}{*}{ Group } & \multicolumn{3}{|c|}{ Number of cases with titer of } \\
\hline & $\begin{array}{l}100 \text { units } \\
\text { or less }\end{array}$ & $\begin{array}{l}\text { Between } \\
100 \text { and } \\
200 \text { units }\end{array}$ & $\begin{array}{l}200 \text { units } \\
\text { or more }\end{array}$ \\
\hline $\begin{array}{l}\text { Mothers............ } \\
\text { Babies. . . . } \ldots \ldots \ldots \ldots\end{array}$ & $\begin{array}{l}29 \\
25\end{array}$ & $\begin{array}{r}7 \\
10\end{array}$ & $\begin{array}{l}1 \\
2\end{array}$ \\
\hline Medical students. . . . . . . & 8 & 1 & 1 \\
\hline $\begin{array}{l}\text { Nurses-probationers } \\
(1931) \ldots \ldots \ldots \ldots\end{array}$ & 14 & 5 & 3 \\
\hline $\begin{array}{l}\text { Nurses-probationers } \\
(1932) \ldots \ldots \ldots \ldots\end{array}$ & 34 & 6 & 0 \\
\hline 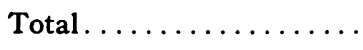 & 110 & 29 & 7 \\
\hline Per cent $\ldots \ldots \ldots \ldots \ldots$ & 75 & 20 & 5 \\
\hline
\end{tabular}

These data are summarized in Table III where it is seen that the median titer for 176 individuals in good health was 83 units. This is significantly higher than the natural level of 50 units.

These findings serve as an index of what may be expected in New York City in the population as a whole. The results show that 75 per cent had antistreptolysin titers of 100 units or less, 5 per cent had titers of 200 units or more, 20 per cent were intermediate. The median ${ }^{3}$ of the 146

3 To facilitate comparisons between groups, medians have been used throughout rather than averages, as it is not mathematically permissible to average quantities of such different magnitudes as the titers in question. 
determinations was 71 units, slightly higher than the natural level of 50 units. This indicates the difference between the range of titers to be expected during "good health" or following other infections and the natural antistreptolysin level of individuals who have been free of hemolytic streptococcus disease for a long period of time.

\section{The range of antistreptolysin titers following hemolytic streptococcus infection}

The authors are in entire agreement with Todd (4) that the presence of an antistreptolysin titer of 200 units or more is strong evidence of recent infection with hemolytic streptococcus. However, in interpreting the significance of titers below 200 units it is important to know the frequency of such levels in persons convalescing from these infections. For this purpose, determinations were made on sera obtained from a number of suitable patients. The readings were of two kinds, single determinations made four weeks after recovery from infection, and determinations made serially for six months following infection.

Single observations in a group of 26 cases showed that 10 per cent (following scarlet fever), 16 per cent (following mastoiditis) and 50 per cent (following pharyngitis) had titers below 200 units. In 24 patients with hemolytic streptococcus pharyngitis whose titers were determined repeatedly, 55 per cent developed maximum levels of less than 200 units. Most of these low titers followed infections contracted during the fall and winter months.4 There was wide variation in the type of titer curve developed. Some individuals (Type A) showed a progressive increase in antistreptolysin level, which reached a peak in five to twenty weeks. Other individuals (Type B) had a sharp initial rise, which was maintained for only a few weeks. Nearly all of the patients developed a secondary rise of titer some months after the primary maximum. Illustrative curves of both types are presented in Figure 1. The

\footnotetext{
4 This seasonal variation is mentioned because the authors have also noted a similar fluctuation in production of toxin and in the frequency with which these infections are followed by a rheumatic attack. In New York City the activity of hemolytic streptococcus appears to be at a minimum in the early autumn, and to increase progressively throughout the winter and spring months.
}

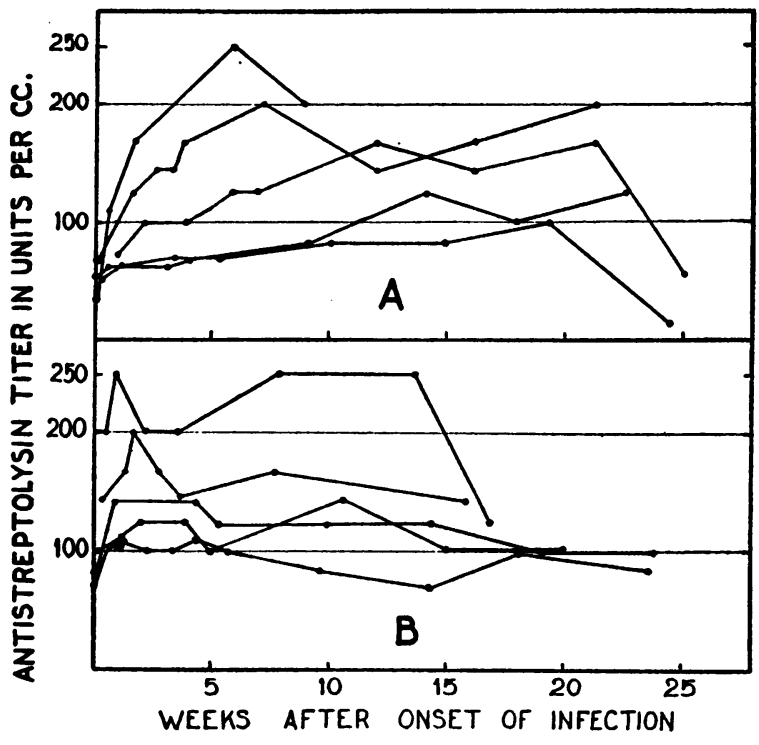

Fig. 1. The Development of Antistreptolysin Titers in Young Adult, Non-Rheumatic Subjects Following Throat Infections with Hemolytic STREPTOCOCCUS.

data for all the single and serial determinations are presented later, along with the observations on rheumatic patients in Table VII.

\section{Antistreptolysin titers during the attack of acute rheumatism}

Working in conjunction with Dr. E. W. Todd, the authors reported finding high antistreptolysin titers in the sera of patients with acute rheumatism (5). Similar studies published by Myers and Keefer (6) of Boston have substantiated these findings in part, but have raised certain questions which it seems advisable to discuss at this point, before presenting any more data. Myers and Keefer agree that the antistreptolysin titer in acute rheumatism is elevated to a level equal to that following proven streptococcal infections; but they question any significance being attached to readings of 200 or 250 units, since 200 was the "average" level of their normal control group. The choice of a few hospital assistants for their " normal control group," may well account for these high readings. The failure of Wilson et al. (7) to detect the significance of the antistreptolysin titer in children with rheumatic fever may result from their use of averages, ap- 
plied at a critical point in their argument to only ten cases. Since titer readings increase geometrically, arithmetic averages are meaningless.

Antistreptolysin determinations have been made in this laboratory on all of the authors' patients with frank attacks of rheumatic fever, those with chorea being excluded. Altogether, the sera of 175 patients were examined in 1933, 1934 and 1935. Single readings were made on the first group of patients; weekly titrations were made in 1934 and 1935 . The results were as follows: In 1933, the median was 250 units, the (geometric) mean 224 ; in 1934, the median was 500 units, the mean 430 units; in 1935, the median was 500 units, the mean 562 . These data are presented in Table VII.

The occurrence of these high titers in acute rheumatism did not appear to depend on the age of the individual. The authors' patients ranged from 18 months to 50 years of age. ${ }^{5}$ The percentage distribution of titer levels in relation to age is shown in Table II.

TABLE II

Percentage distribution of antistreptolysin titers in relation to age, in 271 patients with acute rheumatism 1930-1935

\begin{tabular}{|c|c|c|c|c|c|c|c|c|}
\hline \multirow[b]{2}{*}{$\begin{array}{c}\text { Age } \\
\text { groups }\end{array}$} & \multirow[b]{2}{*}{$\begin{array}{l}\text { Number } \\
\text { of cases }\end{array}$} & \multicolumn{6}{|c|}{ Range of antistreptolysin titers } & \multirow[b]{2}{*}{$\underset{\text { titers }}{\text { Median }}$} \\
\hline & & $\begin{array}{l}50 \\
\text { to } \\
83\end{array}$ & $\begin{array}{c}100 \\
\text { to } \\
167\end{array}$ & $\begin{array}{c}200 \\
\text { to } \\
333\end{array}$ & $\begin{array}{c}500 \\
\text { to } \\
833\end{array}$ & $\begin{array}{c}1000 \\
\text { to } \\
1667\end{array}$ & 2500 & \\
\hline $\begin{array}{l}\text { years } \\
0 \text { to } 2 \\
3 \text { to } 7 \\
8 \text { to } 13 \\
14 \text { to } 21 \\
22 \text { to } 30 \\
31 \text { to } 50\end{array}$ & $\begin{array}{r}5 \\
22 \\
115 \\
72 \\
29 \\
28\end{array}$ & $\begin{array}{l}1 \\
1\end{array}$ & $\begin{array}{r}4 \\
10 \\
21 \\
30\end{array}$ & $\begin{array}{l}20 \\
35 \\
48 \\
48 \\
59 \\
50\end{array}$ & $\begin{array}{l}60 \\
30 \\
24 \\
30 \\
10 \\
17\end{array}$ & $\begin{array}{l}20 \\
30 \\
19 \\
10 \\
10\end{array}$ & $\begin{array}{l}5 \\
4 \\
1 \\
3\end{array}$ & $\begin{array}{l}500 \\
500 \\
333 \\
333 \\
250 \\
250\end{array}$ \\
\hline
\end{tabular}

It is seen in Table II that the titer distributions were approximately the same at all ages. There was a slight tendency towards higher levels in the younger age groups and a similar tendency towards lower levels in adults with acute rheumatism.

5 In 80 per cent of 37 cases studied, blood from the cord of the newborn contained more antistreptolysin than the corresponding maternal blood.

\section{The fall in antistreptolysin titer during subsidence of rheumatic activity}

It was possible to observe 41 of these patients for two years following an attack of acute rheumatism and to obtain sera for titer determinations at appropriate intervals. So far as could be determined, none of these patients was reinfected during this period. The changes in titer levels during convalescence are presented in Table III.

The changes in titer seen in Table III are similar to the observations made at The Pelham Home (1). The rate of fall in titer during convalescence varied markedly. In no instance was the titer higher during recovery than during the acute attack. Sera of all individuals tested at the end of six months showed a fall in titer, with the exception of one child who maintained a titer of 333 units for two years. More than half of the patients had reached natural levels at the end of two years; the remainder had only a slight elevation of titer. The median value for the group at this time was 71 units. In contrast, the median value for the same patients during the acute attack was 250 units. From these observations it is seen that the antistreptolysin titer diminishes as the rheumatic process becomes quiescent. This is believed to indicate subsiding activity of the tissues producing antibody to hemolytic streptococcus.

In summary it is apparent that the range of antistreptolysin titer during the attack of acute rheumatism is (1) similar to that observed during convalescence from scarlet fever, (2) higher than that following hemolytic streptococcus pharyngitis, (3) considerably higher than that of rheumatic subjects apparently quiescent, (4) strikingly higher than that of individuals in good health or with diseases not of hemolytic streptococcus origin.

Serial antistreptolysin determinations make it possible to investigate the time relationship between the development of rheumatic activity and the production of antibodies to hemolytic streptococcus. The authors are of the opinion that although the antistreptolysin titer represents only a fraction of this antibody response, it is the best available index of the total immune response to infection with this agent. The following observations are presented in detail to show a relation- 
TABLE III

Antistreptolysin titers of patients recovering from acute rheumatism (units per cc.)

\begin{tabular}{|c|c|c|c|c|c|c|c|c|c|c|c|c|c|c|c|c|c|c|c|c|c|c|c|c|}
\hline \multirow{2}{*}{ Name } & \multicolumn{4}{|c|}{ Acute rheumatism } & \multicolumn{7}{|c|}{ Symptom free } & \multicolumn{13}{|c|}{ Apparently quiescent } \\
\hline & (Month) 1 & 2 & 3 & 4 & 5 & 6 & 7 & 8 & 9 & 10 & 11 & 12 & 13 & 14 & 15 & 16 & 17 & 18 & 19 & 20 & 21 & 22 & 23 & 24 \\
\hline
\end{tabular}

ship between rheumatic fever and activity of the antibody-producing mechanism.

\section{The relationship between the height of the anti- streptolysin titer attained and the severity of the rheumatic attack}

The authors have studied a group of rheumatic subjects over a period of years to determine the effect of respiratory infections on their disease. The members of this group who developed acute rheumatism showed a coincident rise in antistreptolysin titer with each recrudescence. Furthermore, those rheumatic subjects who appeared to escape activity of the rheumatic process following respiratory infection usually showed little or no change in titer level. Five year observations on two illustrative patients are presented along with their antistreptolysin titer curves. Each of these patients, one child and one young adult, had several respiratory infections with different types of hemolytic streptococcus in the course of the observation period.

\section{CASE HISTORIES}

H. D., Number 69558. The patient, an American boy of Italian parentage, has been under the authors' care since 1928 when he was first seen at the age of seven with rheumatic heart disease. Between 1930 and 1935, he was kept under close clinical observation. Throat cultures were examined each month and blood samples obtained at intervals for antistreptolysin determinations. Two throat infections occurred during the five year period.

The first of these hemolytic streptococcus infections was contracted on February 17, 1934. The patient was admitted to Babies Hospital where he ran the course of acute pharyngitis with a three day fever. On March 1, the sedimentation rate of the blood, which had been falling, showed a moderate rise. He was discharged on the tenth of the month, symptom-free, with, however, an elevated sedimentation rate. Three weeks later he developed a frank attack of polyarthritis, accompanied by marked increase in the sedimentation rate. This attack required hospitalization and prolonged convalescent care.

The patient was again in excellent condition when he contracted the next throat infection, March 9, 1935. He was cared for in the wards of the Presbyterian Hospital. Recovery from acute pharyngitis was rapid and convalescence uneventful until April 2 when the pulse rate, sedimentation rate of the blood and white blood count 
rose slightly and electrocardiographic changes appeared - " $T$ waves have become definitely abnormal suggesting heart muscle damage, possibly active." All of these laboratory changes disappeared within a few days, and the patient was in good condition until April 23 when he developed epistaxis, then polyarthritis, followed on May 1 by a severe rheumatic attack with pericarditis.

Hemolytic streptococcus was recovered from the patient's throat once in 1931 and 1932, but did not appear to cause local infections or initiate rheumatic activity. On February 16, 1934, hemolytic streptococcus appeared in predominance during the period of pharyngitis and persisted until January 1935. On March 9, 1935, the organ-
In summary, it seemed that each of these streptococcus infections was followed by a moderate rise in antistreptolysin titer which then remained constant for two weeks before making a second rise to a higher level. During each period of the lower plateaus, there was laboratory evidence suggesting mild rheumatic activity. With the development of both of the secondary titer rises there was an explosive outburst of rheumatic manifestations. These changes are shown graphically in Figure 2.

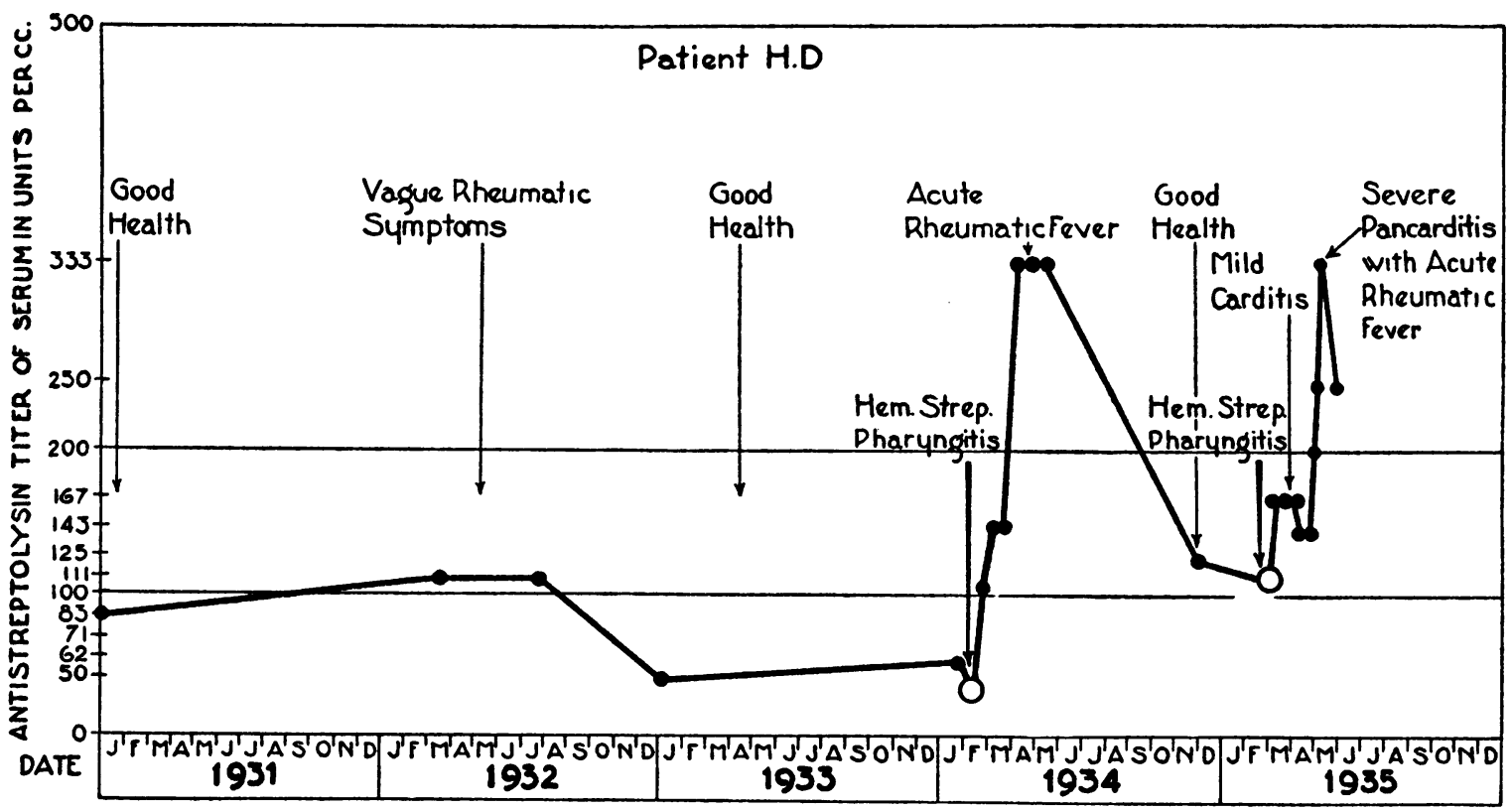

Fig. 2. Changes in Antistreptolysin Level in Patient H. D., Following Hemolytic Streptococcus INFECTIONS FROM 1931 TO 1935

isms reappeared in predominance coincident with the onset of throat symptoms. Sugar fermentation reactions of these two strains of hemolytic streptococcus showed them both to be Streptococcus pyogenes, according to Holman's classification. Studies of the antistreptolysin level were begun in 1930 when the patient was in good health with a titer of 83 units. The titer rose during a period of vague symptoms in the spring of 1932 to 111 units, was 50 units on January 2,1933, when the patient appeared in excellent health. Two weeks after pharyngitis it rose to 144 units, and remained constant for two weeks. Then occurred a rise to 333 units coincident with the onset of acute rhematism. The level had fallen to 111 units when the 1935 throat infection occurred. Following this infection there was a rise to 167 units and then a fall to 143 units at the time that the patient appeared to have escaped recrudescence. However, ten days later the titer rose precipitously to 333 units coincident with the onset of severe pericarditis.
M. O., Number 82235. The second patient, an Irish maid of eighteen, came under the authors' observation in May 1929 when she was admitted to the Presbyterian Hospital with acute rheumatic fever and mitral stenosis. At that time her throat flora contained hemolytic streptococcus. Between 1929 and 1935 she reported monthly for examination and throat cultures. Samples of blood for antistreptolysin determination were obtained at appropriate intervals. During five years of observation she contracted four distinct throat infections.

On February 21, 1931, she contracted acute pharyngitis with fever for three days. Muscle pains, mild pyrexia and tachycardia appeared on March 7, 1931. The electrocardiographic tracing showed extensive migration of the pacemaker. All symptoms and cardiac changes disappeared in one week. On January 13, 1932, she again contracted acute pharyngitis with a three day fever. During the latter part of February vague manifestations were noted. Suddenly, on March 7, 1932, she became 
acutely ill with severe polyarthritis, pyrexia, dyspnea and tachycardia. The electrocardiographic tracing again showed nodal rhythm with shifting pacemaker, and there was a return to normal in one week. Symptomatic recovery from this attack occurred in three weeks. On January 30,1933, she again contracted acute pharyngitis. This infection was severe and was followed by extensive cervical adenitis. While at rest in bed in the Presbyterian Hospital on February 17, 1933, she developed muscle pains, epistaxis, mild pyrexia, leukocytosis and increased sedimentation rate of the blood without electrocardiographic changes. All evidences of rheumatic activity disappeared in five days. On December 29, 1934, she again contracted acute pharyngitis with a three day fever. This infection was followed by three months of excellent health without symptoms, signs or any laboratory evidence suggesting rheumatic activity. Another infection in April, 1935, was followed by a mild rheumatic attack.

The throat cultures from this patient showed the arrival of hemolytic streptococcus on February 21, 1931; on January 13, 1932 ; on January 30,1933 , and on December 29,1934 . This organism was predominant or present in large quantities in both tonsillar fossae during was moderately elevated to 125 units. After the patient had been in good health for eight months the titer fell to the natural level of 50 units. There was no change in titer during the 1932 pharyngitis; however, with the onset of acute rheumatism on March 10,1932, the level rose to 333 units. This was followed by a gradual decline in antistreptolysin level. During the severe throat infection in 1933 the titer reached a value subnormal for this patient, then one week later returned to natural level, and with the onset of mild rheumatic symptoms rose to 111 units and then to 166 units. The patient maintained a constant level of 71 units through 1934. Following pharyngitis in December, 1934, the titer remained practically stationary, and the patient symptom-free. However, another throat infection in April, 1935, was followed by a rise in titer to 143 units, coincident with the development of rheumatic symptoms.

In summary, there was a close correlation between the degree of rheumatic activity and the height to which the antistreptolysin titer rose. In the absence of appreciable change in titer, this rheumatic subject infected with hemolytic streptococcus escaped all clinical and laboratory signs of recrudescence. The changes in antistreptolysin level are presented in Figure 3.

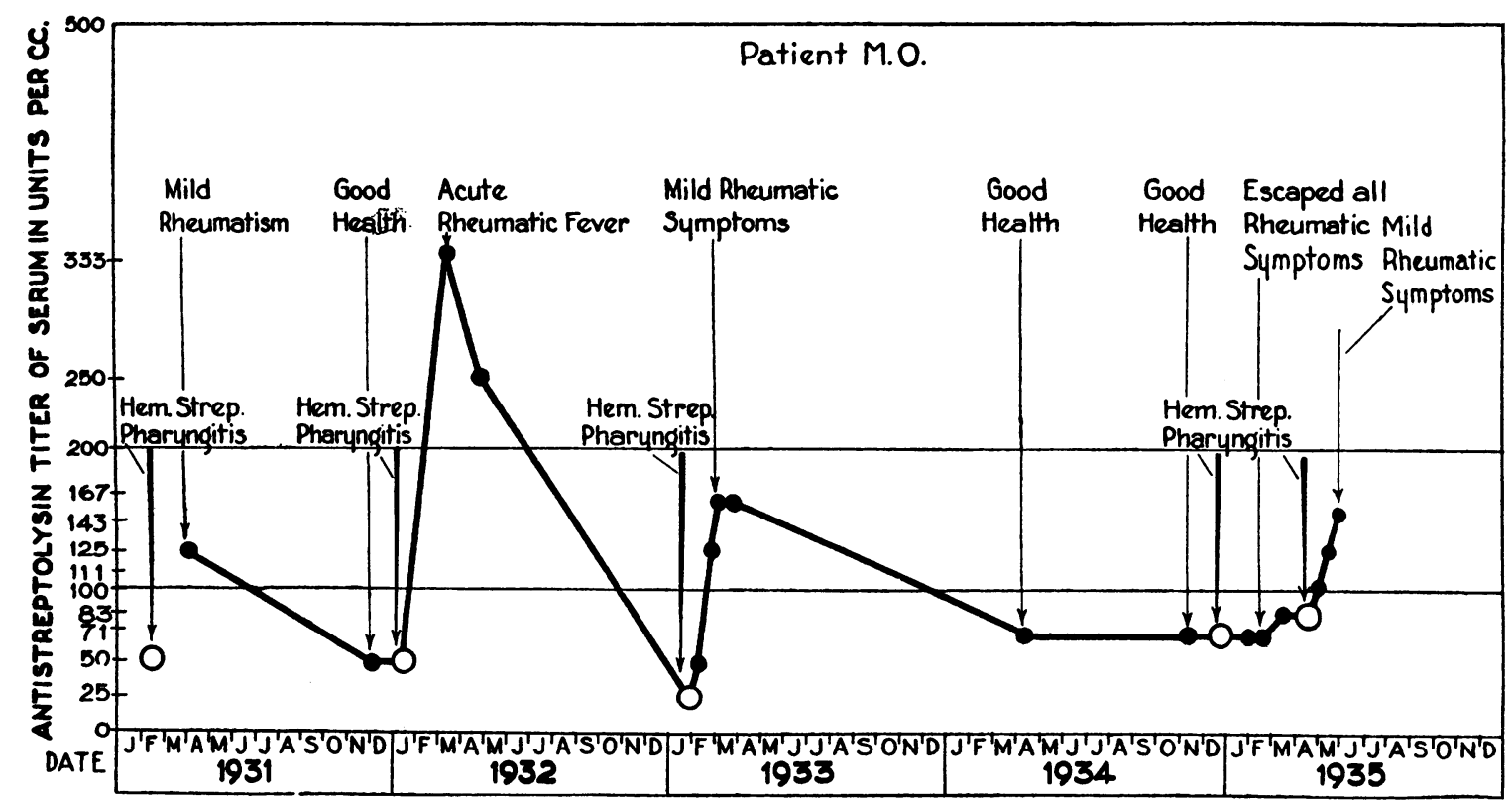

Fig. 3. Changes in Antistreptolysin Level in Patient M. O., Following Hemolytic Streptococcus InfecTIONS FROM 1931 TO 1935

each of these infections and disappeared entirely from the pharyngeal mucosa in one to six weeks with all but the last infection. Studies of the cultural and biological characteristics of these organisms indicated that these infections were caused by different types of beta hemolytic streptococcus.

The antistreptolysin studies were begun during the mild rheumatic attack in 1931. At this time the level
The observations on the two patients just discussed suggest a relationship between the height of antistreptolysin level attained and the intensity of the rheumatic attack. In order to investigate this possibility in a large number of subjects with acute rheumatism, the authors have made serial determinations on 72 consecutive admissions to 
the hospital. All of these individuals had frank character of the rheumatic attack. The individual rheumatic fever, those with chorea being excluded. antistreptolysin readings for the entire group are The subjects have been classified according to the presented in Table IV.

TABLE IV

Serial antistreptolysin determinations (units per cc.) on 72 consecutive admissions with rheumatic fever

\begin{tabular}{|c|c|c|c|c|c|c|c|c|c|c|c|c|c|c|c|c|c|c|c|c|}
\hline Class & Patient & 1 & 2 & 3 & 4 & 5 & 6 & 7 & 8 & 9 & 10 & 11 & 12 & 13 & 14 & 15 & 16 & 17 & 18 & 24 \\
\hline II & $\begin{array}{l}\text { Aquinto } \\
\text { Cahill } \\
\text { Callahan } \\
\text { Carmody } \\
\text { Gatto } \\
\text { Hallett } \\
\text { Hanzar } \\
\text { Howard } \\
\text { Jones } \\
\text { Kokinakis } \\
\text { Kuchinsky } \\
\text { Lord } \\
\text { Mulchione } \\
\text { Neal } \\
\text { Noonan } \\
\text { Santiago } \\
\text { Zwirlein }\end{array}$ & 200 & $\begin{array}{l}500 \\
500 \\
\\
333\end{array}$ & \begin{tabular}{|r|}
333 \\
\\
625 \\
333 \\
714 \\
500 \\
500 \\
\\
1000 \\
714 \\
\end{tabular} & \begin{tabular}{|}
333 \\
\\
333 \\
\\
250 \\
250 \\
500 \\
\\
1250
\end{tabular} & $\begin{array}{r}1250 \\
2500 \\
500 \\
500 \\
625 \\
333 \\
333 \\
833 \\
833\end{array}$ & \begin{tabular}{|r|}
333 \\
2500 \\
625 \\
500 \\
\\
\\
\\
500 \\
333 \\
714 \\
1667 \\
833 \\
1000
\end{tabular} & \begin{tabular}{|r|}
833 \\
333 \\
2500 \\
333 \\
714 \\
\\
333 \\
333 \\
333 \\
714 \\
1250 \\
625 \\
1000 \\
\end{tabular} & $\begin{array}{r}333 \\
1667 \\
\\
833 \\
714 \\
\\
333 \\
333 \\
500 \\
714 \\
1667 \\
714 \\
1000\end{array}$ & $\begin{array}{r}333 \\
333 \\
714 \\
\\
2500 \\
625 \\
625 \\
333 \\
714 \\
714\end{array}$ & \begin{tabular}{|r|}
250 \\
\\
833 \\
500 \\
\\
250 \\
250 \\
500 \\
714 \\
1667 \\
625 \\
1000
\end{tabular} & $\begin{array}{r}250 \\
\\
833 \\
\\
1667 \\
333 \\
333 \\
333 \\
625 \\
1250\end{array}$ & $\begin{array}{r}333 \\
1667 \\
333 \\
\\
250 \\
333 \\
714 \\
1000 \\
556 \\
833\end{array}$ & $\begin{array}{r}1250 \\
250 \\
833 \\
500 \\
833 \\
333 \\
250 \\
\\
625\end{array}$ & $\begin{array}{r}333 \\
2500 \\
1000 \\
833 \\
333 \\
556 \\
625\end{array}$ & $\begin{array}{r}1667 \\
833 \\
1000 \\
250 \\
333 \\
333\end{array}$ & $\begin{array}{r}333 \\
1250 \\
1667 \\
250 \\
333 \\
\\
\\
250 \\
333 \\
333 \\
\\
625\end{array}$ & $\begin{array}{r}1667 \\
250 \\
1000 \\
\\
714 \\
250 \\
250\end{array}$ & $\begin{array}{r}250 \\
333 \\
1667 \\
714 \\
\\
\\
\\
250 \\
333 \\
250 \\
500 \\
250 \\
556\end{array}$ & $\begin{array}{l}333 \\
250 \\
333 \\
625 \\
200 \\
714 \\
\\
\\
111 \\
\\
\\
\\
333 \\
200 \\
333 \\
200 \\
333 \\
500\end{array}$ \\
\hline III & $\begin{array}{l}\text { Allaine } \\
\text { Brown } \\
\text { Delaney } \\
\text { Digerlando } \\
\text { Ellingson } \\
\text { Faiman } \\
\text { Harris } \\
\text { Howe, K. } \\
\text { Israels } \\
\text { Kovner } \\
\text { Murphy } \\
\text { Nurse } \\
\text { Spanos }\end{array}$ & $\begin{array}{l}333 \\
250 \\
200 \\
250 \\
200 \\
500 \\
200 \\
333 \\
250\end{array}$ & $\begin{array}{l}333 \\
200 \\
250 \\
250 \\
250 \\
200 \\
200 \\
500 \\
500 \\
333\end{array}$ & $\begin{array}{l}333 \\
200 \\
250 \\
250 \\
200 \\
333 \\
333 \\
333 \\
333\end{array}$ & $\begin{array}{l}333 \\
250 \\
\\
250 \\
250 \\
333 \\
\\
333 \\
\\
250\end{array}$ & $\begin{array}{l}250 \\
333 \\
333\end{array}$ & 333 & $\begin{array}{l}250 \\
200 \\
125 \\
250 \\
333\end{array}$ & $\begin{array}{l}250 \\
250\end{array}$ & & $\begin{array}{l}125 \\
333 \\
200\end{array}$ & 333 & 250 & & 250 & $\begin{array}{r}111 \\
333 \\
62\end{array}$ & 167 & 200 & $\begin{array}{l}143 \\
200 \\
250\end{array}$ & $\begin{array}{r}250 \\
62\end{array}$ \\
\hline VI & $\begin{array}{l}\text { Comito } \\
\text { D'Amico } \\
\text { Daugherty } \\
\text { Demasi } \\
\text { Earls } \\
\text { Einhorn } \\
\text { Doorley } \\
\text { Goadby } \\
\text { Heinelt, A. } \\
\text { McGirr } \\
\text { Ojia } \\
\text { Ohrbach } \\
\text { Roos } \\
\text { Starrett } \\
\text { Temestocle } \\
\text { Walsh, C. } \\
\text { Walsh, G. }\end{array}$ & $\begin{array}{l}333 \\
250 \\
333 \\
333\end{array}$ & $\begin{array}{r}250 \\
500 \\
\\
1000 \\
333 \\
\\
500 \\
333\end{array}$ & $\begin{array}{r}333 \\
500 \\
333 \\
\\
250 \\
1000 \\
500 \\
333 \\
333 \\
\\
\\
\\
\\
\end{array}$ & $\begin{array}{l}250 \\
\\
333 \\
556\end{array}$ & \begin{tabular}{r|}
200 \\
333 \\
1000 \\
\\
333 \\
333 \\
333
\end{tabular} & $\begin{array}{r}250 \\
200 \\
833 \\
200 \\
333 \\
\\
\\
\\
1000 \\
\\
\\
250 \\
250 \\
500 \\
333\end{array}$ & $\begin{array}{r}167 \\
200 \\
\\
333 \\
1000 \\
333 \\
250 \\
500\end{array}$ & $\begin{array}{l}250 \\
\\
333 \\
333 \\
143 \\
833 \\
\\
333\end{array}$ & $\begin{array}{l}200 \\
333\end{array}$ & \begin{tabular}{r|}
250 \\
333 \\
333 \\
333 \\
500
\end{tabular} & $\begin{array}{l}250 \\
333\end{array}$ & $\begin{array}{l}200 \\
625 \\
333 \\
200 \\
125\end{array}$ & $\begin{array}{l}333 \\
125 \\
\\
\\
333 \\
125\end{array}$ & 714 & $\begin{array}{l}333 \\
100\end{array}$ & 625 & $\begin{array}{l}250 \\
200 \\
555 \\
200\end{array}$ & 250 & $\begin{array}{r}83 \\
250 \\
250 \\
125\end{array}$ \\
\hline
\end{tabular}


The classes in Table IV have been defined as follows :

Class I-Fulminating polycyclic attack with intense pancarditis.

Class II-Continuous, severe carditis, insidious in onset.

Class III-Severe monocyclic polyarthritis with mild carditis.

Class IV-Severe polycyclic polyarthritis with mild carditis.

Class $V$-Mild, vague rheumatic attacks of short duration.

Class VI-Mixed types.
Class I. Most of the patients who survived for three weeks or more developed extremely high antistreptolysin titers. Two died during the first week of the attack probably before the titer levels had reached maximum values. A similar observation was made during The Pelham Home epidemic (1). Illustrative titer curves are presented in Figure 4.

Class II. Most of these individuals came under observation late in the rheumatic attack and, although symptom-free, developed rapidly progressive carditis while at rest in bed. All of these children developed extremely high antistreptolysin levels, as shown in sample curves, Figure 4.

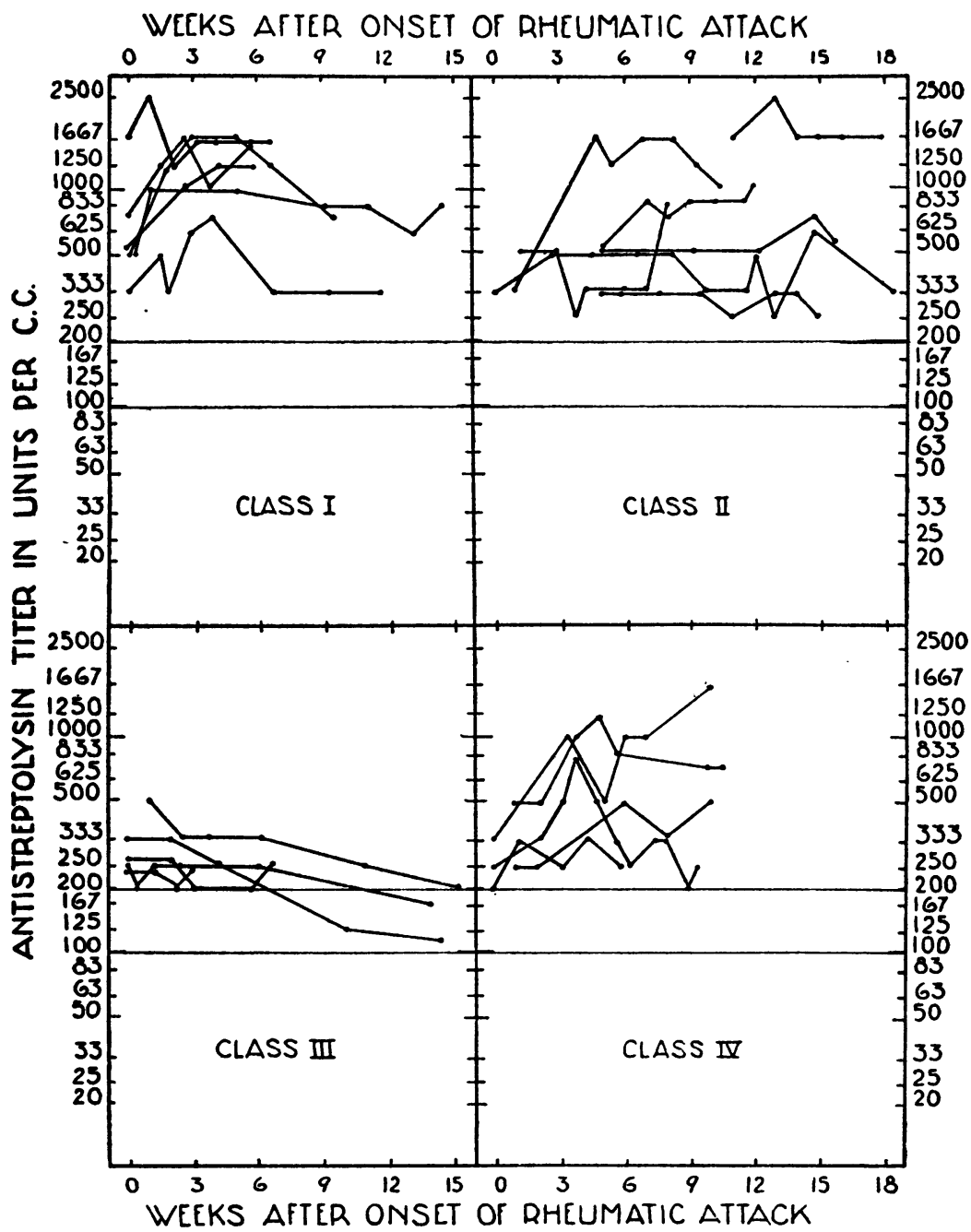

Fig. 4. Antistreptolysin Titer Curves of Four Clinical Types of Patients with Rheumatic Fever 
Class III. These patients had severe but brief rheumatic attacks without serious carditis. The disease process seemed to subside rapidly and spontaneously. The attacks were limited to a single cycle of approximately two weeks duration. None of the titers exceeded 500 units at any time and all tended to fall shortly after the disappearance of symptoms. Illustrative curves are shown in Figure 4.

Class $I V$. In contrast, these patients who at first were clinically similar to those in Class III, developed repeated cycles of polyarthritis. These exacerbations were accompanied by marked increases in titer levels, bringing them into the titer range of Classes I and II. See Figure 4.

Class $V$. These patients had vague manifestations with laboratory findings indicating mild rheumatic activity. Recovery was prompt and in most instances the titer levels were only slightly elevated.

Class VI. These individuals presented a mixed clinical picture. It has been considered advisable to exclude them from the well defined groups.

In summary, it appears that extremely high antistreptolysin levels (over 500 units) are associated with intense or prolonged rheumatic activity. The lower levels seem to be associated with acute rheumatism that is either short in duration or mild in character. These observations are believed to indicate that the intensity of the rheumatic attack is associated with the degree of activity of the subject's antibody production to hemolytic streptococcus.

\section{The relationship between the rise in antistreptoly-} sin titer and the onset of rheumatic activity

Another relationship suggested in the titer curves in Figures 2 and 3 is the coincidence of a sharp rise in titer with the onset of the rheumatic attack. This observation was found to be true in The Pelham Home epidemic (1). In order to study this time relationship in a significant number of cases, the authors made determinations on 30 patients during hemolytic streptococcus pharyngitis, the quiescent interval and the attack of acute rheumatism. The determinations for the entire group are presented in Table V.

TABLE V

The development of antistreptolysin titer (units per cc.) between hemolytic streptococcus infection and the rheumatic attack

\begin{tabular}{|c|c|c|c|c|c|c|c|c|c|c|c|c|c|c|c|c|c|c|c|c|c|c|}
\hline \multirow{2}{*}{ Patient } & \multirow{2}{*}{$\begin{array}{c}\text { Before } \\
\text { in- } \\
\text { fection }\end{array}$} & \multirow{2}{*}{$\begin{array}{l}\text { During } \\
\text { in- } \\
\text { fection }\end{array}$} & \multicolumn{7}{|c|}{$\begin{array}{l}\text { Quiescent interval } \\
\text { (weeks) }\end{array}$} & \multicolumn{12}{|c|}{$\begin{array}{l}\text { Acute rheumatism } \\
\text { (months) }\end{array}$} & \multirow{2}{*}{$\begin{array}{c}\text { Character } \\
\text { of } \\
\text { attack }\end{array}$} \\
\hline & & & 1 & 2 & 3 & 4 & 5 & 6 & 7 & 1 & 2 & 3 & 4 & 5 & 6 & 7 & 8 & 9 & 10 & 11 & 12 & \\
\hline 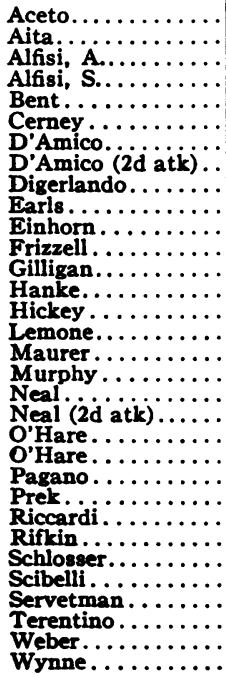 & $\begin{array}{r}200 \\
20 \\
125 \\
167 \\
50 \\
71 \\
125 \\
250 \\
63 \\
33 \\
83 \\
143 \\
143 \\
100 \\
50 \\
83 \\
100 \\
50 \\
100 \\
\\
71 \\
33 \\
50\end{array}$ & $\begin{array}{r}25 \\
25 \\
\\
250 \\
25 \\
50 \\
111 \\
83 \\
250 \\
50 \\
250 \\
33 \\
50 \\
125 \\
125 \\
200 \\
250 \\
50 \\
100 \\
\\
100 \\
83\end{array}$ & \begin{tabular}{|r|}
25 \\
\\
500 \\
71 \\
100 \\
167 \\
\\
333 \\
125 \\
167 \\
33 \\
50 \\
200 \\
166 \\
250
\end{tabular} & 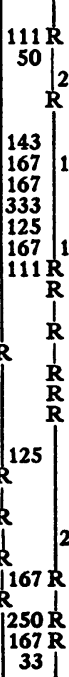 & 167? & $\begin{array}{l}143 \\
143 \\
R \\
R \\
R \\
167\end{array}$ & $143 R$ & $2^{143 R}$ & $\mathbf{R}$ & \begin{tabular}{|r|}
500 \\
125 \\
200 \\
250 \\
1667 \\
1250 \\
333 \\
333 \\
250 \\
500 \\
500 \\
250 \\
200 \\
200 \\
500 \\
250 \\
500 \\
333 \\
500 \\
1000 \\
333 \\
143 \\
200 \\
143 \\
250 \\
333 \\
200 \\
250 \\
250 \\
500 \\
200 \\
250
\end{tabular} & $\begin{array}{r}1000 \\
125 \\
167 \\
333 \\
2500 \\
500 \\
250 \\
250 \\
556 \\
250 \\
500 \\
1000 \\
500 \\
2500 \\
1000 \\
833 \\
250 \\
2500 \\
333 \\
250 \\
250 \\
250 \\
\\
250\end{array}$ & \begin{tabular}{|r|}
125 \\
167 \\
1667 \\
333 \\
\\
333 \\
\\
1000 \\
500 \\
\\
\\
1667 \\
250 \\
250 \\
167 \\
250 \\
500 \\
250 \\
250
\end{tabular} & $\begin{array}{l}250 \\
250 \\
143 \\
\end{array}$ & 167 & $\begin{array}{r}1250 \\
143\end{array}$ & 250 & $\begin{array}{l}250 \\
125 \\
\\
200 \\
333 \\
250\end{array}$ & & $\begin{array}{r}111 \\
50 \\
143 \\
\end{array}$ & $\begin{array}{c}200 \\
250 \\
167 \\
56 \\
143 \\
100\end{array}$ & $\begin{array}{r}50 \\
33 \\
125\end{array}$ & $\begin{array}{l}\text { Severe } \\
\text { Severe } \\
\text { Mild } \\
\text { Mild } \\
\text { Severe } \\
\text { Severe } \\
\text { Moderate } \\
\text { Moderate } \\
\text { Mild } \\
\text { Moderate } \\
\text { Moderate } \\
\text { Mild } \\
\text { Moderate } \\
\text { Moderate } \\
\text { Severe } \\
\text { Moderate } \\
\text { Severe } \\
\text { Mild } \\
\text { Moderate } \\
\text { Moderate } \\
\text { Moderate } \\
\text { Mild } \\
\text { Severe } \\
\text { Moderate } \\
\text { Moderate } \\
\text { Moderate } \\
\text { Moderate } \\
\text { Moderate } \\
\text { Severe } \\
\text { Severe } \\
\text { Severe } \\
\text { Mild }\end{array}$ \\
\hline
\end{tabular}

* $\mathrm{R}$ indicates time of onset of rheumatic symptoms. 
It is seen in Table $\mathrm{V}$ that the onset of each rheumatic attack occurred at the time that the antistreptolysin titer was rising. The development of the rheumatic attack coincident with the immune response to hemolytic streptococcus has been a consistent finding during these studies.

The maintenance of low antistreptolysin level in rheumatic subjects who escaped recrudescence following hemolytic streptococcus
pharyngitis

The authors have pointed out (5) that when rheumatic subjects are infected with hemolytic streptococcus, some develop frank recrudescences; others get mild rheumatic symptoms and the rest appear to escape rheumatic activity entirely. The present section concerns itself with the last of these groups of patients. Their titer changes are presented in Table VI. lar observations are to be found in Figure 2, in an earlier paper of this series (2), and were also made in the epidemic at The Pelham Home (1). Representative titer curves of patients who developed attacks and of those who did not are shown in Figure 5.

All of the titers discussed in this study have been classified in Table VII with reference to their frequency distribution. The logarithms of the units have been used as a basis for classification, (a) to correct for the skewness of the distribution of titer units on an arithmetic scale, and (b) thus permit the calculation ${ }^{6}$ of means and probable errors, and the determination by statistical methods of the significance of differences between groups. As already mentioned, the titers of the first five groups are taken from single determinations and those in the last seven groups represent the maximum of a series of determinations.

TABLE VI

Antistreptolysin titers (units per cc.) in individuals with streptococcus pharyngitis not followed by rheumatic attacks

\begin{tabular}{|c|c|c|c|c|c|c|c|c|c|c|c|c|c|c|c|c|c|c|c|c|c|c|}
\hline \multirow{3}{*}{ Name } & \multirow{2}{*}{\multicolumn{2}{|c|}{ Pharyngitis }} & \multicolumn{20}{|c|}{ After pharyngitis } \\
\hline & & & \multicolumn{18}{|c|}{ Weeke } & \multicolumn{2}{|c|}{ Months } \\
\hline & Before & During & 1 & 2 & 3 & 4 & 5 & 6 & 7 & 8 & 9 & 10 & 11 & 12 & 13 & 14 & 15 & 16 & 17 & 18 & 6 & 12 \\
\hline 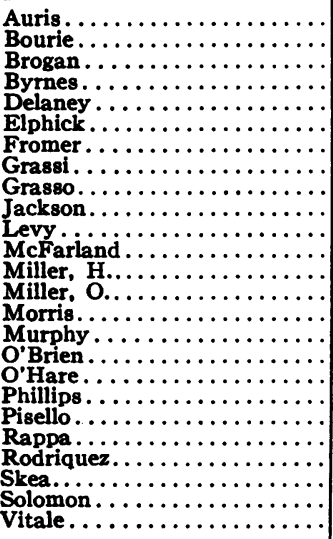 & $\begin{array}{l}125 \\
125 \\
\\
71 \\
50 \\
71\end{array}$ & $\begin{array}{r}50 \\
125 \\
71 \\
50 \\
333 \\
167 \\
333 \\
83 \\
143 \\
143 \\
100 \\
12 * \\
83 \\
111 \\
71 \\
71 \\
71 \\
250 \\
33 \\
167\end{array}$ & $\begin{array}{r}50 \\
167 \\
143 \\
50 \\
71 \\
200 \\
250 \\
250 \\
333 \\
71 \\
63 \\
143 \\
\\
71 \\
83 \\
71 \\
50 \\
125 \\
71 \\
50 \\
33 \\
167\end{array}$ & $\begin{array}{r}167 \\
167 \\
50 \\
250 \\
250 \\
71 \\
143 \\
111 \\
167 \\
\\
71 \\
125 \\
83 \\
50 \\
33 \\
5\end{array}$ & $\begin{array}{r}50 \\
167 \\
71 \\
200 \\
250 \\
250 \\
71 \\
143 \\
143 \\
111 \\
125 \\
100 \\
\\
50 \\
111 \\
200 \\
33\end{array}$ & $\begin{array}{r}200 \\
167 \\
100 \\
250 \\
63 \\
143 \\
111 \\
143 \\
125 \\
71 \\
71 \\
\\
33 \\
143\end{array}$ & $\begin{array}{c}167 \\
\\
250 \\
250 \\
333 \\
143 \\
111 \\
111 \\
71\end{array}$ & $\begin{array}{l}111 \\
143 \\
143\end{array}$ & $\begin{array}{r}333 \\
\\
71 \\
71 \\
\end{array}$ & 125 & 143 & 143 & $\begin{array}{r}83 \\
143\end{array}$ & 125 & 333 & 250 & & & & $\begin{array}{r}71 \\
125\end{array}$ & $\begin{array}{l}143 \\
125 \\
125\end{array}$ & 50 \\
\hline
\end{tabular}

* This infection was severe and probably accounts for the depressed titer level.

It is seen from Table VI that in individuals contracting pharyngitis with hemolytic streptococcus not followed by rheumatic recrudescence, the antistreptolysin titer either fell, remained stationary or rose slightly. These titer levels are in distinct contrast to those of patients who developed frank attacks of acute rheumatism. Simi-
6 The statistical methods used in this paper were taken from Garrett, H. E., Statistics in Psychology and Education. New York, Longmans, Green and Company, 1926. The calculation of those probable errors which depend upon relatively few cases (13 or less) was made by the formulae of R. A. Fisher, as given by Dunn, H. L., Physiol. Reviews, 1929, 9, 275. 


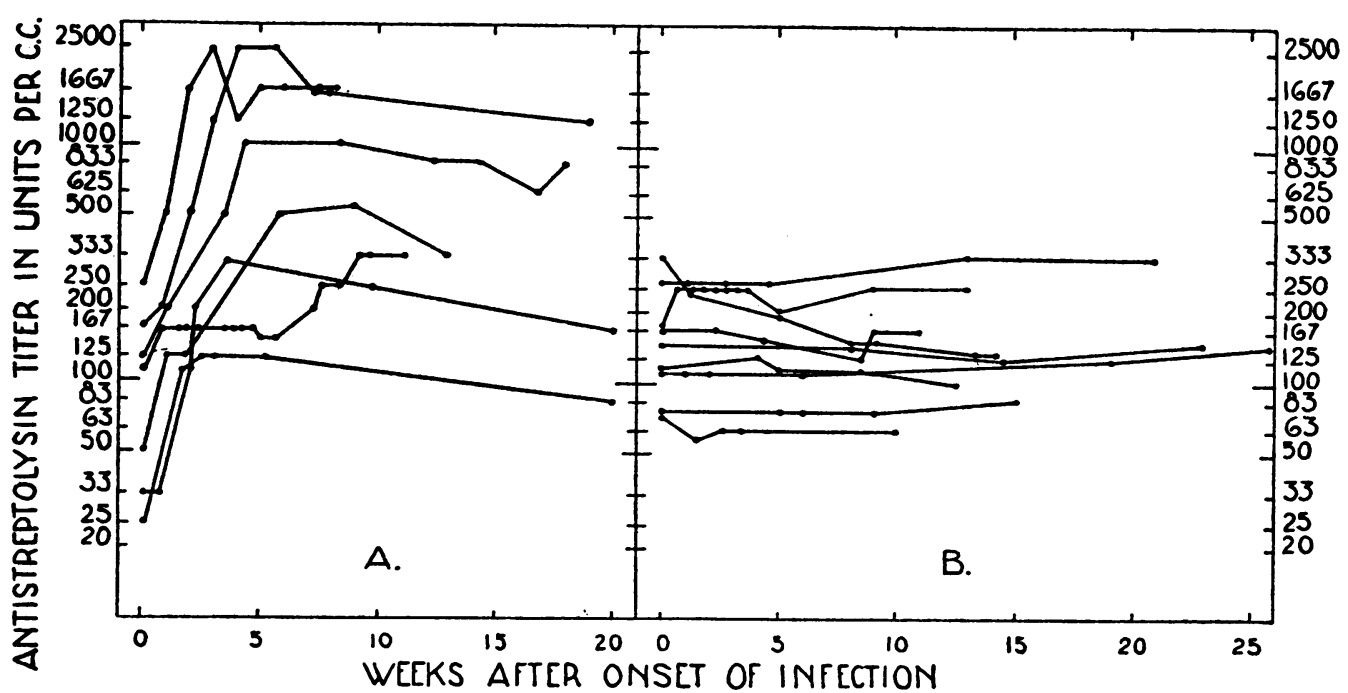

Fig. 5. Antistreptolysin Titer Curves of Rheumatic Subjects During and After Hemolytic Streptococcus Pharyngitis

$A$. Developed rheumatic attacks.

$B$. Escaped rheumatic attacks.

As is seen in Table VII the geometric means (calculated from the average $\log u$ ) differ only slightly from the medians. This indicates that the logs of the titers have an approximately normal distribution. In view of the probable errors of the average $\log u$ 's, the following conclusions can be drawn: (a) There is no significant difference between Group 1 and 2; (b) Groups 3, 4, and 5 are significantly higher than both 1 and 2 ; (c) There is an apparent difference between Groups 4 and 5; however, because of the small number of cases in Group 4, it is unwise to draw conclusions; $(d)$ Groups 6 and 3 are almost identical; (e) Group 7 is significantly lower than 6 and $8 ;(f)$ The average mean $\log u$ of Groups 7 and 8 does not differ significantly from the mean $\log u$ of Group 6; $(g)$ There is no significant difference between Groups 8, 9 and 10; $(h)$ The differences between these three groups and Group 5, which are significant, may be attributed to the method of collecting material; ( $i$ ) Groups 11 and 12 are significantly lower than Groups 8, 9 and 10.

From the data obtained in 1934 and 1935, the range of titers to be expected with rheumatic fever in terms of log units is $2.69 \pm 0.31$ (S.D.). This will include $2 / 3$ of such cases, and the range of $2.69 \pm(3 \times 0.31)$ will include practically all patients with acute rheumatism. Expressed in units this range corresponds to titers of 240 to
1260 units for $2 / 3$ of the cases with the largest number falling at about 490 units. $^{7}$

The patients who escaped recrudescence following pharyngitis with hemolytic streptococcus (Group 7) showed distinctly less antistreptolysin response to infection than either. non-rheumatic subjects following comparable infection or patients with acute rheumatism. This cannot be attributed in all cases to the nature of the infecting agent (2) but in some instances seems to be associated with a diminished immune response of the host.

\section{DISCUSSION}

Sufficient data are not yet available to determine whether the antibody response of the rheumatic subject differs from that of the non-rheumatic subject. This discussion will therefore be confined to rheumatic subjects. The data presented for this group show wide variations in the antibody response to hemolytic streptococcus infection. These variations seem significant in determining the development of rheumatic activity. In general, the greater the antibody response, the more severe the accompanying rheumatic attack; and conversely, in the absence of antibody response the rheumatic attack fails to develop. The

${ }^{7}$ The authors are indebted to Dr. A. A. Weech for advice in applying statistical methods to these data. 


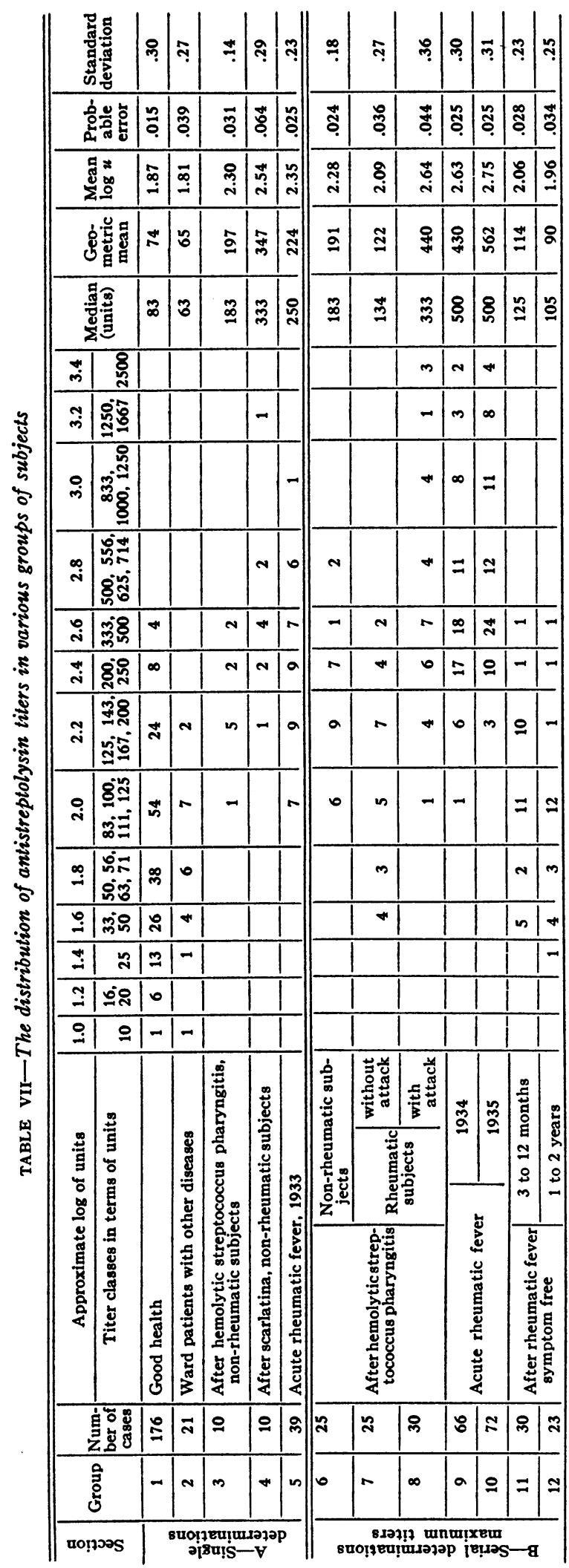

titer level attained by any individual patient seems to be the result of at least three factors : the character of the infecting strain, the intensity of the patient's response to that particular infection, and the capacity for antibody production characteristic of the individual. The close time relationship between the antistreptolysin rise and the onset of rheumatic activity, together with the close correspondence between the absence of such rise in titer and the quiescence of the rheumatic process, has led to the belief that the association is not accidental. However, the mechanism responsible for the simultaneous occurrence of these immunological and clinical changes remains to be determined. One of a number of possible explanations is dealt with in the following paper (8).

\section{SUMMARY}

The median of the antistreptolysin determinations on 176 individuals in good health was 71 units. This is somewhat higher than the natural human level of 50 units.

The median titer developed in acute rheumatism was 500 units, and the geometric mean 490 units. In most instances the titer returned to approximately natural level within a period of one year.

The onset of acute rheumatism coincided with a sharp rise in antistreptolysin titer.

Rheumatic patients infected with hemolytic streptococcus who escaped recrudescence, showed little or no change in antistreptolysin titer.

The relation of the immune response of the host to the development of rheumatic activity is discussed.

\section{BIBLIOGRAPHY}

1. Coburn, A. F., and Pauli, R. H., Studies on the immune response of the rheumatic subject and its relationship to activity of the rheumatic process. II. Observations on an epidemic of influenza followed by hemolytic streptococcus infections in a rheumatic colony. J. Exper. Med., 1935, 62, 137.

III. Observations on the reactions of a rheumatic group to an epidemic infection with hemolytic streptococcus of a single type. Idem, 1935, 62, 159.

2. Coburn, A. F., and Pauli, R. H., This series. IV. Characteristics of strains of hemolytic streptococcus effective and non-effective in initiating rheumatic activity. J. Clin. Invest., 1935, 14, 755.

3. Coburn, A. F., and Pauli, R. H., This series. I. The determination of antistreptolysin titer. J. Exper. Med., 1935, 62, 129. 
4. Todd, E. W., Further observations on the virulence of hemolytic streptococci, with special reference to the morphology of the colonies. Brit. J. Exper. Path., 1928, 9, 1.

5. Coburn, A. F., and Pauli, R. H., Studies on the relationship of streptococcus hemolyticus to the rheumatic process. III. Observations on the immunological responses of rheumatic subjects to hemolytic streptococcus. J. Exper. Med., 1932, 56, 651.

6. Myers, W. K., and Keefer, C. S., Antistreptolysin con- tent of the blood serum in rheumatic fever and rheumatoid arthritis. J. Clin. Invest., 1934, 13, 155.

7. Wilson, M. G., Wheeler, G. W., and Leask, M. M., Antistreptolysin content of blood serum of children. Its significance in rheumatic fever. Proc. Soc. Exper. Biol. and Med., 1934, 31, 1001.

8. Coburn, A. F., and Pauli, R. H., This series. VII. Splenectomy in relation to the development of rheumatic activity. J. Clin. Invest., 1935, 14, 783. 